\title{
THE THEOLOGICAL DILEMMA VIS- À-VIS THE MORAL OPTIONS FOR RELEVANT AND PRACTICAL MINISTRY TODAY: LESSONS FOR THE ZIMBABWE COUNCIL OF CHURCHES
}

\section{Sifiso Mpofu}

Department of church history and church polity, University of Pretoria

smpofu@zol.co.zw

\section{ABSTRACT}

There are many misconceptions about the role of the church in society. This is because the church is neither a political institution nor a social organisation but a mystery of grace. The church can best be defined or understood in terms of its mission or its work. This article will explore the mission and work of the Christian church; specifically the church in Zimbabwe. One cannot talk about the Christian church without reflecting on Jesus Christ's mission. The church is the body of Christ, the true representative of the broken body of Jesus Christ. Paradoxically, while church leaders say that they are concerned about the poor, the downtrodden, the oppressed, they seem not to fight against harmful socioeconomic and political structures that dehumanise many of God's creation. The church, as God's compass to direct humanity for the total good of all creation, should always advocate in favour of peace and social justice. Christian leaders have a moral and social responsibility in their proclamation of the gospel of Jesus Christ in an environment which is characterised by despondency, uncertainty and fear. This paper identifies moments of prophetic resistance to social evil. It is to be noted that such a prophetic dimension is an enduring reality of the life of an authentic church, despite the complex (and at times compromising) relationship between church and state. This article proposes possibilities for a new paradigm shift in Christian ministry with a view toward a rebirth of a socially conscious church within the established platform of Christian ministry.

Key words: Zimbabwe Council of Churches; Christian church; theological dilemma;

\section{UNISA $\cong$}

Studia Historiae Ecclesiasticae Volume 41 | Number 1 | 2015 pp. $67-85$
DOI: http://dx.doi.org/10.17159/2412-4265 /2015/v41n1a6 Print ISSN 1017-0499 | Online 2374-3689 (c) 2015. Studia Historiae Ecclesiasticae 
role of the church; moral responsibility; prophetic responsibility.

\section{Introduction}

The greatest challenge today, for the church in Zimbabwe, is how to be relevant and authentic in a broken society characterised by conflict, corruption, selfishness, fear and despair in the midst of a polarised political environment. In the context of such a society, people tend to question the justice of God and the relevance of the church as a primal move toward the search for justice. Theologically, the church is an assembly of the faithful who are called out to be instruments of grace in a broken world. The understanding of the church as an instrument of grace to a broken world is based on the Biblical text that the believers/disciples are the salt and light of the world - a metaphor of justice and righteousness (Matthew 5:13-16). The church as an instrument of grace defines the missiological nature of the church in terms of its authority to 'preach... and provide humanitarian work to improve economic development...health care' (Missiology: www.wikipedia.org/wiki/Mission). Calvin P. Van Reken in his social justice writings argues that the church as an institution has a legitimate responsibility to the people that she exists for:

The church as an institution is a formal organization that sets out to accomplish a specific purpose. It is an agent. It can do things; it can say things; it has its own voice. As an institution, it has its own purposes and plans, its own structure and officers, and its own mission. It has its own proper sphere. It many ways it parallels other institutions, like governments or schools. Working for the church makes you a church worker. (Church: www.calvin.edu/ academic/philosophy.pdf accessed 26/10/2014)

However, in Zimbabwe today, there is general suspicion that the church may have lost its essence of being 'salt and light' through the glaring silence of the church's leadership in the midst of the political and social evils which characterise society. This assertion is based on the lack of a clear prophetic voice of the church in the context of the imploding economic and political catastrophic trends. What remains paramount is the fact that the mandate of the church is its divine designation which does not depend on the sinful nature of the church's leadership. The church's leadership only has an instrumental function and not a substantive role. The church's leadership merely acts as the conveyer belt. In his article Prophecy, politics and power: Changing relations between the Catholic Church and the Zimbabwean state (1980-2007), Gundani observes:

At the heart of Christianity is the conviction that God has a purpose for creation, and that her will impinges on the history of the world. In keeping with this conviction, the Church, as a community of believers, consistently tries to interpret God's will in order to align their lives and the lives of those around them to God's will. (Gundani 2008. www.paulgundani. com accessed 23/07/2013) 
From an authentic theological perspective, the mission of the church cannot be understood and fulfilled outside the world in which it exists, because its concern is not only the individual's relationship with God but also the relationship between the same individual and the world in which he/she lives. In a time when ideological pragmatism 'distorts seeing and deafens hearing' (Villa-Vicencio 1986, viii), an authentic church with relevant modes of ministry remains the only option for promoting a faithful and practical discourse within the present reality in an attempt to move toward a 'meaningful future'. Theologically, the church is modelled around action and praxis propelled by the desire to image Christ's mission of redeeming the world from all forms of societal evil, as evidenced by the declaration: 'I came that they may have life, and have it abundantly' (John 10:10b). It then follows that the church's prophetic role in the context of social disintegration and national polarisation demands a socio-political and economic engagement with the relevant arms of governance and political players toward a socio-political contract which will give birth to peace and democratic space for all. Any other option would be a disgrace to the church of Jesus Christ who came to declare the good news to all.

\section{Lessons from history: Church-state relations}

The full text of this argument is grounded in the primary lessons of history; because Christianity is a historical religion, hence the need for a brief historical analysis of the key lessons of church history. The story of Christianity shows that it is possible 'to read the Bible as a textbook on the pathology of religion giving rise to hypocrisy, idolatry, group egotism and collective blindness' (Villa-Vicencio 1986, xv). On the other hand the Bible can be read as a therapeutic text overcoming the maladies of society by being a source of political renewal (Baum 1975, 62-84). The Christian church has always played an ambiguous socio-political role throughout its history. In some cases, the church has blessed and legitimated the state (post-Constantine era) while at times, the church (observably some individual characters) has rejected the status quo by affirming the reign of God and by calling for social justice against political evils of the state.

The first Christians were uncompromisingly confrontational with regard to the secular order. They believed that the state was ungodly while on the other hand the state also viewed Christians as being in a 'deadly collision with the Roman Empire' (Hastings 1926, 208). The writings of Tacitus (60-120) as preserved in Documents of the Christian church (Bettenson 1964, 1-6) show that the early church was uncompromising in its mission: 'All the endeavours of men, the entire emperor's largesse and the propitiations of the gods, did not suffice' (Bettenson 1964, 1-2) to destroy the resolve of the church fathers. The case of Bishop Polycarp, a Christian martyr who took a clear stance against the evil systems of the Roman Empire justifies the theology of the early church when he said: '... spiritual authority impinged on the 
political realm in both judgment and renewal' (Epistle concerning martyrdom of Polycarp 1, 37).

The post-Constantine era (312CE) allowed the church to become an ally of the state; emperors became the compatriots of the bishops. In the same spirit "the sovereign autocrat was inevitably and immediately involved in the development of the church, and conversely the church became more and more implicated in high political decisions' (Chadwick 1988, 125). The emperors saw Christianity as a means of promoting social stability for the common good of the empire. During the medieval era, St Augustine's imperial theology promoted a critical solidarity between church and state, hence he could argue that at times the church has to say no and at times yes to state ideologies (Brown 1969, 289). Augustine argued that it was the obligation of the Christian to bring the state into order because Christians are 'an assembly of reasonable beings bound together by a common agreement as to the objects of their love' (St Augustine, Civitas Dei, XIX, 24). Augustine operated on the level of a thin trajectory because he believed that even though the church was superior to the state, the state was also obliged to help the cause of the church whenever it mattered most. Clearly, such thinking has some parallels in Zimbabwe today.

The sixteenth century Reformers also sought to maintain rapport between church and state, hence Martin Luther argued that 'God has ordained two governments: the spiritual by which the Holy Spirit produces Christians and the righteous people under Christ; and the temporary, which restrains the un-Christian and wicked so that - no thanks to them - they are obliged to keep still and to maintain an outward peace' (Villa-Vicencio 1986, 50). In the same vein, John Calvin argued that people must obey the law but they also must be mindful that God is higher than the human law. However, Calvin believed that even though the state was a necessary institution it was never perfect because it was managed by fallible mankind (McNeill 1965, 31-32). In his work Institutes of the Christian religion; Book $1 \mathrm{~V}$, Calvin argues that civil disobedience against evil systems of governance is a right of all people, just as we learn through the actions of Daniel who refused to obey the impious decree of Nebuchadnezzar (Daniel 6:22) (Calvin 1936. Institutes of the Christian religion). In the mind of Calvin, it is clear that the church is meant to be the final arbiter for peace in the world where sin and evil seek to destroy that which is good.

The modern church is characterised by powerful justice-conscious movements within the established church denominations. These movements have promoted popular pastoral declarations and affirmations which have become the rallying point of the social renewal spirit in church circles. The Barmen Declaration (1934) is one such statement during the crisis of Nazism. The declaration rejected the established church agenda by refusing to theologically absolutise a particular political programme. Bonhoeffer was inspired by the Barmen Declaration and 'acted as a responsible and brave man' (De Gruchy 1984, 16). Bonheoffer (1993) defended 
the weak and the poor by attempting to affirm God's love and justice in the context of political and social evils. This is a good lesson regarding the meaning and cost of discipleship, emphasising that there is no neutral ground for the church when it comes to matters of faith and justice.

In Latin America, the Medellin Conference (1968) addressed issues of faith and justice in an honest way. This conference was a culmination of small theological reflection groups which began in an era of political subjugation. The Medellin Conference declared that the authentic message of the gospel of Jesus Christ was contrary to false and evil 'political, social and economic systems which were responsible for the oppression of the masses' (Medellin Conference 1968). In South Africa, the Kairos Document (1985) (Kairos [Kaıpós] in ancient Greek means right or opportune moment - the supreme moment) was the high point of active participation in the socio-political arena by individual Christians. The Kairos Document deplored the apartheid system as an evil crisis which impinged on God's justice for all creation. It condemned the abuse of religion for political gain (Kairos Document, Chapters 1 \& 2). It called for a prophetic theology which is the authentic message of the gospel truth (Kairos, Chapter 4). The lessons from both Medellin and Kairos are enough to inspire the Zimbabwean Church to act as the salt and light of the nation in the search for peace and justice for all.

\section{Kairos for mission: Whither to, church of Zimbabwe?}

Bianchi (quoted in Dulles 1987) argues that the church 'as one of the principal agents whereby the human community is made to stand under the judgment of the enduring values of the Gospel of Jesus Christ' (Dulles 1987, 96) must act within the structures of our contemporary age rather than parallel to them, if it is to be a relevant instrument of grace to the hurting world. In this perspective, the church must be 'a herald - one who receives an official message with the commission to pass it on' (Dulles 1987, 76). In his missiological analysis of the role of the church today, Bowen argues that the church can only survive when it is able to develop through different phases that affect people in real life (Bowen 1996, 70).

The relevant and authentic Christian ministry is borne out of the church's Kairos moment. Kairos implies a sense of urgency, the decisive or crucial moment or point (Kittel 1968, 456). The Kairos moment for mission, therefore, becomes the destiny which calls the church for decisive action in its salvific work. Through the church, 'God issues a challenge to decisive action...It is a dangerous time because if missed, and allowed to pass by, the loss for the Church, for the Gospel' (Kairos Document $1985,1)$ and for humanity will be immeasurable. We deduce from Christ's message that the abiding motive for mission 'is love, and we have seen that Christian love is the self-giving that lets-be' (Macquarie 1977, 444). This notion evolves from the cry: 'come over to Macedonia and help us' (Acts 16:9-10). For the church to realise its 
mission, it must take cognisance of the fact that the modern world order has sought to be independent from God, hence the chaos and disorderliness of our times. In this regard, the church's mission must always shine with new splendour, radiate new light and activate new insights in reaching out to a broken world.

The Zimbabwe Council of Churches' (ZCC) role in the promotion of democracy and good governance in Zimbabwe must be driven by the desire to make this world a better place for all creation. This role of the church (her calling and her mission) is stated in Luke 4:18 'to set free the oppressed'. This aspect of mission must be visible and audible through the church's social gospel movement. In the article, Church activism: A mission and a calling to be attained, Mpofu observes that:

If the Church's programmes are far removed from issues of social justice, good governance, the democratic rights of the citizens and a concern for a quality life for all, then such a Church cannot truly claim to be a manifestation of the Kingdom of God on earth. (Mpofu 2013. n.p. www.zimbabweinstitute.com accessed 13/08/2013)

As to the nature of the church, theologians generally agree that the church is 'a living and loving community,' it is a manifestation of 'the kingdom of God on earth'. This understanding of the church shows that the church is a transforming and empowering community; it is the continued presence of Jesus Christ on earth. From this realisation, the church cannot afford to be indifferent and isolated in the face of the glaring socio-political and economic decay in Zimbabwe, which has become both a disgrace and a scandal to the goodness of God's beautiful creation. Perceiving the mission of the church from this perspective, Bonheoffer says the church is truly the church when it fights for the salvation of others (Bonheoffer 1993, 174).The church has to appreciate the reality that the world needs its ministry, hence it must pray to the Lord of Life for divine help as it seeks to bring sanity and peace where humanity has failed to realise these fundamental principles of life.

The foundation for an authentic, relevant and practical ministry is motivated by divine justice and compassion for the marginalised children of God: 'I have heard the cry and seen the suffering of my people' (Exodus 3:7) as well as Jesus' declarations: 'I came that all may have life and have it abundantly' (John 10:10); 'My peace I leave with you' (John 14:28). The ministry of Jesus Christ points to the fact that Jesus' interest was the common good of the people he preached to. He was interested in the people's everyday experiences, hence the declaration: 'Come to me all who labour and are heavy burdened and I will give you rest' (Matthew 11:28). The lesson from this text is a warning against an indifferent attitude by the institutional church when the same people that she seeks to serves suffer pain and perpetual suffering from social evils. What is currently happening in Zimbabwe is that the ZCC tends to shy away from making public comments which rebuke those who trample down the rights of ordinary citizens, and yet in the early years of Zimbabwe's independence the ZCC issued pastoral letters which spoke to the situation without fear or favour. 
A good example is the April 1980 pastoral letter, Our call to peace and justice as the nation is born, where the ZCC observed that 'there is need for the government to unite the nation for the common good of all...the institution of the church becomes one of the few places of hope toward social dialogue and social healing' (ZCC Newsletter, April 1980). The 1980 message has to be re-lived by the churches in Zimbabwe today for the ZCC to be authentic and relevant.

In the context of a politically polarised nation, the institutional church becomes one of the few fountains of hope in the struggle towards national reconciliation and healing. The preaching of the gospel of Christ should not be mere polemics when people need practical guidance on issues of life and death. The church can either support the status quo or call for its overhaul. If the church chooses the first option, then it will have chosen to side with the 'devil' in co-oppressing the suffering masses who are calling for liberation and justice. The second option of calling for the overhaul of the situation follows the Jesus methodology of bringing liberty to the oppressed: 'The Spirit of the Lord is upon me...He has sent me to proclaim liberty to the captives and recovering of sight to the blind, to set at liberty those who are oppressed'(Luke 4:18-19). The proclamation of liberty to the captives is the essence of being church, as defined by the ministry of Jesus Christ. Bonhoeffer's theology in the crisis of World War II declares that the church is the place where testimony and serious thought is given to the reconciliation of the world which she seeks to save (Bonhoeffer 1993, 127). Such proclamation must motivate preachers to be honest. A holistic approach towards an authentic theological discourse takes note that God's salvific plan is non-selective and is premised on the call for peace, justice and restoration without fear or favour. A living theology of the church has to appreciate that there is need for both internal and external critique of ministry and service alike, as well as rulers and systems of governance. Failure to take note of this aspect can result in a selective approach to the church's prophetic responsibility.

\section{The Zimbabwe Council of Churches' pastoral responsibility today}

A brief description of Zimbabwe and its political state of affairs as well as the ZCC's ecumenical responsibility will serve the interests of this paper. Zimbabwe is a landlocked country in southern Africa, bordered by the Zambezi River to the north and the Limpopo River to the south. Zimbabwe attained its independence from British rule on 18 April 1980 under a Zimbabwe African National Union - Patriotic Front (ZANU PF) government. Hallencreutz and Moyo $(1988,12)$ observe that the ZANU (PF) election manifesto of 1980 promised to 'respect and promote the role of the Church and avoid completely interfering with the spiritual work of the Church'. However, the same document also added a particular clause that 'the Church and the state must thus feature as partners in the promotion of the welfare of the human 
being' (Hallencreutz and Moyo 1988, 12). Can this be the beginning of the church's polarisation? Since 1980 Zimbabwe has been ruled by one political party under the leadership of President R.G. Mugabe. For over a decade now:

\begin{abstract}
Zimbabwe has a fragile political environment, and the Zimbabwean economy is underdeveloped due to decades of economic mismanagement and political uncertainty... Much of the country's infrastructure is in disrepair and emergency medical care is limited. (Human Development Report 14 March 2013, United Nations Publications: accessed 18 May 2013)
\end{abstract}

Zimbabwe is predominantly a Christian nation constituted by many Christian denominations. The major protestant churches come together under an umbrella body called the ZCC. The ZCC was formed in 1964 as a fellowship of Christian churches and the founding goal was to co-ordinate the work of the church 'in response to the political and socio-economic problems' (ZCC: www.zcc.co.zw accessed 16/08/2013). Currently the ZCC argues that it exists to bring 'together the Church and Christian organizations for joint action, witness, and coordination, particularly to adopt a united and common response to the political and socio-economic problems' (ZCC: www.zcc.co.zw accessed 16/08/2013). Clearly, the socio-political challenges in Zimbabwe present a huge pastoral potential and challenge in carrying out the mandate of Jesus Christ for the ZCC and the church in particular.

What is of interest is that while around 75 per cent of the population claims to be Christian, very few seem to live by the letter and spirit of the Christian values of love, peace and justice. When it comes to the political ideologies, the political field is characterised by violence. Observably, there is no common mind in theological traditions concerning the means at the church's disposal to deal with social evils manifest through unjust systems and structures of governance. But considering the numerous accounts of God's revelation in history, it is clear that God's majesty is inextricably bound to social justice and holiness; hence Baum observes that 'the sacred becomes the bearer of a judgment on human life and society; and of a promise for the righting of present ills' (Baum 1980, 35).

What is clear is that true religion has to concern itself with human and social transformation as it does with the spiritual dimension of life. It is this reality which must inform Christian leadership that God's justice makes men and women tremble because God judges the sinful world and God's holiness is attractive; not because it offers consolation, but because it promises to turn right-side up a world that has been placed upside-down because of sin and evil. Seeking to be relevant in the context of the prevailing national challenges, the ZCC (ZCC January 2013) declared in its pastoral letter: Work for peace in Zimbabwe: Pray for it! Speak it! Spread it! Do it! (Isaiah 60:1-22):

We have a God given Biblical and theological mandate to guide the nation and all leaders in making God's voice to be heard at particular times when He chooses to speak to His people 
on issues of justice, peace, reconciliation, poverty and the liberation of the oppressed (Luke 4:18-19). As the custodians and facilitators of God's mission, we are obliged to "stand up and proclaim" the will of God, whenever His people are faced with difficult situations that seem to deny them fullness of life (John 10:10). In the same way we applaud and encourage positive actions and developments. We continue to do so as in conformity with our calling through preaching the Gospel of truth, justice, peace and love as entrusted to us by the Lord Jesus Christ. (ZCC January 2013)

In this pastoral letter, the ZCC sought to exercise its priestly, prophetic and pastoral responsibility in a responsible manner. This thrust learned from Jesus' message in Luke 4:18ff: ' $\ldots$ he has anointed me to preach deliverance to the captives, to heal the broken hearted, to preach the gospel to the poor, and recovering of sight to the blind, to set at liberty them that are bruised.' Therefore, the church cannot afford to ignore daily human tragedies if it seeks to remain relevant. From this message, it is clear that Christianity is about the moral, social, political and spiritual transformation of the whole being and his/her environment. Therefore, confessing faith in the transcendent God of the Bible within our socio-political context is also a call to challenge the contemporary political and social ills of our day. The vision of ZCC, which is the establishment of a 'compassionate society that is one, just, peaceful, prosperous, dignified and passionate for holistic salvation', must motivate it (ZCC) to be a means of grace to the nation (ZCC: www.zcc.co.zW accessed 16/08/2013).

\section{Relevant modes of pastoral ministry for today's church}

In the Zimbabwean situation today, pastoral ministry develops and grows around the priestly, pastoral and prophetic offices. These three offices symbolise the significant roles in pastoral ministry. Collectively, the three offices represent both the evangelical and social responsibility of the church. These offices complement each other in achieving the purpose of making this world a better place to live in.

From a theological view point, a priest represents people to God and God to people. Priests are mediators between the human and the Divine. Priests follow obedient ethics as they seek to interpret the 'Word of God' through ethics of grace and goodwill in order to balance deontology and teleology (obedience and results). In today's language a priest stands in the gap. The key role of intercession is representative of the priestly office in the true spirit of meditation and mediation. This theological thrust is generally popular in the Catholic tradition.

A theological understanding of the pastoral office projects a pastor as a shepherd. The key role of a pastor is to tend/feed the flock. A pastor is a visitor and a healer of the broken souls through his/her message of comfort and restoration. A pastor is more concerned about the end goal/results - teleology. In essence, pastors look for utilitarianism (the greatest happiness for the greatest number), but with a particular 
eye on the dispossessed. They drive or lead people toward eternal life (the goal). Pastors spend their energy trying to get people to the doorsteps of heaven.

A prophet is a charismatic and fearless messenger of God. A prophet speaks/ declares divine oracles of faith without any attempt to edit the message. A prophet calls people to order and right action. A prophet warns, corrects, rebukes and encourages people toward keeping a clean sheet. Prophets seek to make a difference; they fight for both moral and social justice and tell forth the consequences of disobedience or indifference. They are concerned about deontology (obedience to the will of God). A prophetic ministry does not compromise the universal truth that the church believes in.

\section{What then should be the church's mission in Zimbabwe today?}

Hodgson $(1988,23)$ says 'what formed ecclesial existence is the power or act or work of God'. The church has its beginning in the mind of God but it exists for the good of the people of God. This shows that the church exists for the good of the world, hence the need for the church to be an agent of peace (shalom as comprehensive positive peace and harmony distinguished by justice throughout society) in a hurting world. The message of Isaiah 2:2, Joel 2:28-29 and Daniel 2:44 visualises the kingdom of God being established in the last days and all nations flowing to it and the Lord pouring His Spirit upon all flesh. The fulfilment of these prophetic oracles implies that the church is actively engaged in the business of saving lives and building institutions of peace for the common good of God's people.

Like any institution, the church's mission provides the reasons for its existence. When one talks about the mission of the church, therefore, one talks of that unique and profound task of both the church in its corporate sense and every Christian person. 'Mission is first and last about God. He initiates it [and] completes it; God is always the subject of mission' (Autton 1971, 78-79). The gospel ethic is paramount to the church's missionary agenda, hence it has been argued that 'mission creates the Church, so mission comes before the Church's theology' (Richardson 1983, 316). The mission of God emanates from Jesus' commissioning of the disciples - the church, 'Go, therefore and make disciples of all nations' (Matt. 28:19-20). From this perspective, the ZCC states that it seeks 'to develop more effective ecumenical witness, study and action at local, national and international levels' (ZCC: www.zcc. co.zW accessed: 16/08/2013) by committing itself to:

- Continue calling for divine calmness and unity of purpose for all Zimbabweans.

- Work together in healing the wounds and making Zimbabwe a great nation once again. 
- Be prophetic in rebuking all forms of injustices from any quarter.

- Provide pastoral care to those who are in need.

- Continue to preach peace, love and justice in all our churches more so now and in future.

- Avail ourselves to actively observe the forthcoming elections.

- Finally, we challenge the nation to rise above party petty politics and, in humility and under the guidance of God be constructively engaged in prayer and finding positive approaches to nation building. Let us live in peace and encourage peace as the Lord says "Peace I give to you, my peace I leave with you John 14:27". (ZCC March 2008)

The church is therefore called upon to be an instrument of grace through which Christ's salvific mission is proclaimed for the good of all creation. This can only happen if and when the church adheres to its mission. The mission of the church, therefore, 'describes what God is like and also what the Church is like... [it] bridges the gap between the Church and the Kingdom of God' (Bowen 1996, 12). This implies that the church 'exists by mission as a fire does by burning' (Brunner, cited by Bowen 1996, 12). What then is the motive of mission? We deduce from Christ's message that the 'abiding motive...is love, and we have seen that Christian love is the self-giving that lets-be' (Macquarie 1977, 444). Mission, therefore, is the task of the church to identify itself with the world, even to 'lose' itself for the sake of the world it seeks to serve. This evolves in the cry of the oppressed: '... come over to Macedonia and help us' (Acts 16:9-10). In its press statement of 16 March 2008, the ZCC noted issues of violence that dehumanised the dignity of the people of Zimbabwe and declared the need for tolerance and non-violence:

The church believes in non-violence and it is our hope that all stakeholders should resort to non-violent acts when carrying out their political activities. Even Jesus as He was facing death did not believe in violence. (Luke 22:49-51) (ZCC March 2007)

What does it mean to be a council of churches in light of the prophetic role of the church? What does it mean to be engaged in the mission of God today, in light of the great commission: 'Go ye and make disciples' (Matthew 28:19)? The above stated rhetorical questions help me to contextualise this argument. If the mission of the church is to make sense in the Zimbabwean context today, then those who preach the word of God must ask themselves the following questions: What is our own contribution to social decay and what can we do to salvage the situation? What is Christ saying to us today in the context of His mission to the world? In its pastoral letter of 21 January 2013, the ZCC notes the need for the politicians and church leadership to "work together to offer the fruits of love, which are, among others: 
reconciliation, tolerance, peace, and justice' (Galatians 5:22) (ZCC January 2013). However, the only disturbing thing is that these press statements always remain academic. The reason for lack of action in press statements can be associated with the ZCC's failure to be prophetic in the proper sense, as did the Old Testament prophets who made noise until they were heard or listened to (as in the case of Elijah and Ahaz - 1 Kings 18:20-46).

In Zimbabwe's socio-political challenges, the role of the ZCC is to advance the unfinished business of the church by fighting for justice and peace in the land. Peace is Jesus' gift to the church: 'Peace I leave with you; my peace I give to you. Not as the world gives do I give to you' (John 14:27). In this context the mission of the church must not point to itself but to the event of God. In affirming this, Dulles argues that the church's 'mission is not additional to its being. It exists as it is sent and active in its mission' (Dulles 1987, 78). It is the responsibility of the ZCC (church) to measure up to the ideals of the community. The church should have its roots in the common needs of the people since it is expected to liberate the people, just as Jesus declared: 'The Spirit of the Lord has sent me to proclaim liberty to the captives...to set at liberty those who are oppressed' (Luke 4:18). It is of fundamental importance that the church is shaped primarily by social structures in terms of its vision, mission setting and implementation strategies. However, the church is unique in that it remains the creative work of the Spirit of God. The ZCC believes that there is no salvation or liberation outside the boundaries of the church, hence the church must 'bring total salvation to all and total elimination of poverty - toward enabling the Church to take up its prophetic role' (ZCC: www.zcc.co.zw accessed $16 / 08 / 2013)$.

The only way through which the ZCC can fulfil its mission of promoting peace and justice in the land is through its commitment to advocate for open structures of governance and respect of people's rights. The church must link people to God and to one another so that there is trust and mutuality. With the Lordship of Jesus Christ as its banner, the church should justify its faith through its works. As Cone $(1986,114)$ notes: 'The transcendent origin of the Church [must never be] used as a camouflage to cover up the gross shortcomings of so-called Christian churches.' Sadly, many church leaders readily declare that they are concerned about the downtrodden, the oppressed and neglected citizens, yet they seem not to be willing to fight against the dangerous and barbaric socio-political conditions which are a travesty to justice and peace. The Zimbabwean crisis is not only politically motivated, it is also economically motivated. There is a temptation to focus on things that will give 'relief from poverty, sickness or family problems' (Maxwell 2006, 185) while the focus must be on the promotion of justice, peace and righteousness. The struggle for survival by the poor reveals an enormous contradiction between the rich and the poor who share the same values and worship in the same church. One is forced to pose a question: Is the affluence of the elite the cause of poverty for the wretched masses? 
It is from this paradigm that the church should give birth to a vision that seeks to eradicate the social injustices that create negative class struggles.

Sadly, the church is not spared from the demon of wealth accumulation while its congregants go hungry. The money is used for two things: a) building mansions on earth (state-of-the-art church buildings); and $b$ ) extravagant bonus payments to the pastor. The prophet Ezekiel decried such a situation: 'Look, this was the iniquity of your sister Sodom: she and her daughter had pride, fullness of food, and abundance of idleness; neither did she strengthen the hand of the poor and needy' (Ezekiel 16:49). Interestingly, the picture of the Messiah in Isaiah 61:1-2 portrays a king who protected the oppressed and the poor. In Zimbabwe, the rich and powerful continue to prey on the poor while the pastor is praying. Therefore, the church should set a clear agenda toward redeeming the situation caused by socio-economic injustices, because it is a disgrace to all good and loving citizens just as God is against all forms of oppression which are implicit or explicit in our communities. Thus, the church should stand up and directly attack the structures that promote economic suffering of the masses. In its pastoral letter of January, 2013 the ZCC spoke:

We condemn in the strongest terms possible the cancerous and toxic scourge of corruption that is spreading within our society and call upon the authorities to take decisive measures to end corruption. Zimbabwe's development is retarded on account of millions of dollars lost to corruption. (ZCC: www.zcc.co.zW accessed 08/08/2013)

If the church takes a back seat in the journey of human existence, then it loses its taste as the salt of the world. Such a church becomes irrelevant to the people because it is seen to be a part of the structure of exploitation and exclusion. Therefore, the message of the church should promote the total liberation of humanity from all structures and forms of evil which deprive people of the enjoyment of their Godgiven life, freedom and peace. As the presence of Christ in the world, the church must shape a new vision toward the total good of all. This is why Cone (1986, 144) says 'we should never allow a theological interpretation of the Church [of a transcendent origin] to obscure the empirical behaviour of churches that deny what Church people affirm in their ecclesiological confessions'. So, even if the origin of the church is beyond this world, the theological understanding of the church should be considered in tandem with the prevailing socio-political and economic conditions. In the face of socio-political conflicts between the powerful and less powerful, the church should not wash its hands like Pontius Pilate or pretend to be neutral. Rather, the church must act like Jesus Christ who stood up against the powerful Sadducees and Pharisees without fear or favour:

Then Jesus said to the crowds and to his disciples, The scribes and the Pharisees sit on Moses' seat, 3 so practice and observe whatever they tell you - but not what they do. For they preach, but do not practise. They tie up heavy burdens, hard to bear, and lay them on people's shoulders, but they themselves are not willing to move them with their finger. (Matthew 23:1-4) 
The tendency for church leaders to be comfortable in their enjoyment of the pleasures and perquisites of this world (while the people they preach to are trampled down by the evil structures of society promoted by the rich and powerful), is ungodly and must be condemned as such. Christianity should not be simply spiritualised because it is basically a way of life in its holistic sense; it is an essential ingredient for existence and the promotion of good. This perspective of Christianity projects a clear prophetic responsibility which demands an honest condemnation of sociopolitical structures in which violence and conflicts are bred. The call for prophetic responsibility challenges the church to be more pragmatic in its mission. Sadly, the ZCC has tended to be academic with regard to its prophetic responsibility; merely issuing press statements without action. There is clearly a lack of sufficient organisational capacity and inadequate staff to implement economic justice and legal aid support.

According to Kambudzi $(2000,35)$ the church must stand above national political interests and be seen by all citizens and political authorities to be nonpartisan, neutral and human-centred in its nature, just as it did during the 1960s and 1970s during Zimbabwe's liberation war when the church stood up to the political structures that promoted social injustices and proclaimed life for all. The church now tends to play a low profile which is non-prophetic. This article acknowledges the varied pastoral letters which have been issued by the ZCC, but most of these pastoral letters have made no impact and the churches have not acted in pursuit of their mandate. It would seem that the pastoral letters are simply meant for public relations and nothing more. This is justified by the pronouncements of Bishop Peter Nemapare during the church's mediation initiatives on the crisis that gripped the nation post 2008 disputed general elections:

We know we have a government that we must support, interact with and draw attention to concerns. Those of us who have different ideas about this country must know we have a government which listens. (The Zimbabwean: 15-21 June 2006, 22)

Many citizens tend to interpret the lukewarm attitude of the church as compliance with the state's institutions of repression and its ideology. Yet it is the divine mandate of the church to be concerned about the well-being of God's people, just as God was concerned about the welfare of the Hebrews who were slaves in Egypt: 'I have surely seen the affliction of my people who are in Egypt...and I have come down to deliver them out of the hand of the Egyptians' (Exodus 3:7-8). In his fight for the oppressed, Freire $(1970,55)$ argues: 'The oppressed have been destroyed precisely because their situation has reduced them to things.' The church's agenda today should be to fight for the restoration of people's identity and dignity in the face of their suffering, by naming and shaming sin and evil. Sadly, many church leaders seem to be dining with the same political figures that are at the centre of oppression, brutality and the abuse of the rule of law. Such church leaders have become empty vessels that are never taken seriously by anyone. The declarations of Mafinyane, 
(then General Secretary of ZCC) justify this viewpoint when he says 'the Church fully supports Government's actions as its members were also in need of land... the two must consult and maintain their partnership' (The Zimbabwean, 15-21 June 2006, 22).

In pursuit of justice for all, the ZCC should empower people to seek justice, enable them to visualise a new society that they aspire to live in, and motivate them to take part in God's acts of salvation toward the enjoyment of a new world order. The avenues for pursuing justice are available through its church and society desk, which can easily produce fliers, banners and pamphlets on issues of justice and peace as well as conduct workshops through mobile and immobile clinics for both clergy and laity. Such a prospect is clearly visualised in Revelation 21:1-4:

Then I saw a new heaven and a new earth, for the first heaven and the first earth had passed away, and the sea was no more. And I saw the holy city, New Jerusalem, coming down out of heaven from God, prepared as a bride adorned for her husband. And I heard a loud voice from the throne saying, "Behold, the dwelling place of God is with man. He will dwell with them, and they will be his people, and God himself will be with them as their God. He will wipe away every tear from their eyes, and death shall be no more, neither shall there be mourning nor crying nor pains anymore, for the former things have passed away".

Historically, the willingness to change (on the part of political players) comes about when ecclesiastical institutions rise to challenge the stakeholders who are beneficiaries of the unjust social structures and ideologies. Toward this goal, in September 2006, the ZCC, working with other ecumenical bodies like the Zimbabwe Catholic Bishops' Conference (ZCBC) and the Evangelical Fellowship of Zimbabwe (EFZ) scored a 'pastoral coup' when they produced a document entitled The Zimbabwe we want. This document 'expresses the Church's perceived National Vision'. However, the document did not bind anyone to action since it was called a discussion document. Nevertheless, The Zimbabwe we want, observes: 'Unpleasant instances of political intolerance, violence, impunity and lack of transparency and accountability continue to rear their ugly head within our evolving National Democratic Culture' (ZCC September 2006. The Zimbabwe we want, 2006, 5). Sadly, the document remained an academic paper on the library shelves. This lack of action demonstrates the ZCC's lack of an authentic sense for mission in the context of a national crisis.

In the context of the varied socio-political evils that bedevil the nation of Zimbabwe, one is forced to ask: For how long should the church leadership remain in their cocoons when its membership lives in fear and under oppression? Does the pulpit not provide the Kairos moment to take action and condemn the injustices that have scandalised the nation for a decade now? The church has to rise above fear and be a beacon of hope for the sake of the poor and oppressed citizens who also tend to be the majority in the church's membership. As the centre of hope, the church should engage in the fight for radical but positive change for the liberation of humanity. The church, therefore, must be the active subject and the world as the object that the church acts upon or seeks to reform. 
It is noted that many Zimbabweans have been dehumanised through tyrannical structures which promote bad governance to the point of voluntary servitude. It is from this context that this article agrees with Dube $(2006,67)$ when he says that some church leaders 'have been buried alive religiously, culturally, economically and politically'. The church should demystify the false image of the state which creates fear amongst the ordinary poor citizens. It has to be remembered that the power of a tyrannical state thrives on fear and ignorance. The Bible says 'where there is no prophetic vision the people perish' (Proverbs 29:18). The church's mission of promoting life and peace in the land also entails its willingness to expose all forms of moral and social evils. The church should have the courage to speak truth to power. Silence on the part of the church leads to an element of hopelessness amongst the oppressed masses, thereby leading them to question the love of God; later on God's existence in the context of sin and evil. It is the role of the church to liberate people; to preach freedom from all forms of socio-political injustices which bedevil the society. This is the Kairos time for the church, to restore fallen humanity back to God.

In the context of human existence, the church's mission must shine with new splendour, radiate new light and activate new conquests in search of peace and salvation for all. The ZCC declared in April 1980: 'We acknowledged the promising positive national developments that we anticipated following the attainment of independence and pray that those entrusted with the powers to govern will do so for the common good of the nation'. Now it is also desirable that the ZCC rebukes those who have scandalised the vision and promises that came with the country's independence. Indeed peace, justice and freedom are the mottoes of the corporate values of any society; hence the mission of the church must not only focus on spiritual aspects but also seek to address the socio-political and economic aspects of life. The church that fulfils this mandate becomes the true image of Jesus Christ who came to this world so that all can have life in its abundance: 'I came that they may have life and have it abundantly' (John 10:10b).

The church must be conscious of the fact that throughout the Biblical text the accounts of God's activities relate very closely to the marginalised communities and the ordinary citizens whose existence is threatened by those who rule over them. Therefore, in response to the glaring social evils of our times, the church has to make its Sunday worship services, weekly Bible studies, prayer sessions and other services both pastoral and prophetic in a priestly manner. The repentance which is proclaimed must be named. The sin which is often talked about must be named. All of the church's worship services must be a Kairos (a moment of truth) for its audience. Once it is established that there is moral and social evil in the land, the church has to engage in special programmes to name, shame and eradicate the evil. These social campaigns must be clearly focused and properly managed so that the church avoids falling into a political trap by becoming the third force (a force between 
the oppressor(s) and the oppressed). This is a moral and social responsibility of the church. It is a non-violent approach or campaign in the context of civil disobedience. It is the brave ACT of faith.

\section{Conclusion}

From a social and historical perspective, it is common for people to turn to religion and religious institutions for solutions to those problems that they lack power to deal with. From the aforesaid perspective, the Christian church (as the largest single religious institution in the land) has a moral responsibility to guide and counsel people toward fighting for justice and peace in the land; the total good for God's creation. It becomes imperative for the Christian church in Zimbabwe to be proactive in educating people about their rights and duties as citizens - this is its moral responsibility. Theologically, to emphasise social stability at the cost of renewal or to insist on the indiscriminate dismissal of the social order in affirmation of God's eschatological kingdom, is to fail to be Christo-centric.

From a theological viewpoint, it is proper to argue that without the church's vision and guidance, the Zimbabwean society (which is largely Christian) stands in danger of becoming moribund. The established fundamental thrust is that the church must be the face of Christ in a hurting world so that it can bring about peace, justice and freedom to all. It is therefore paramount that genuine church leaders should be able to discern God's plan for an effective ministry in any setting and act as prophets and priests toward truth telling and healing of the social order. Both academics and church leaders have a moral obligation to show the face of Christ in their society they live in without fear or favour, because duty calls them to act.

This analysis of the mandate of the church in Zimbabwe today has only touched on certain salient factors and areas critical for the moral options relevant for practical Christian ministry in Zimbabwe today. We conclude that a church without a relevant ministry in a crisis situation is like a lost coin at sea. As a motivating factor the postmodern church in Zimbabwe can learn from the examples of the early church through the modern era. This article salutes Peter C. Hodgson $(1988,137)$ who argues that: 'The fundamental purpose of ministry is to guide and serve the process of ecclesial formation, ecclesial preservation, and ecclesial mission - that is, to enable the church to realise its ecclesial essence, to be a community of faith, hope and love, a sign and sacrament of the kingdom of God.'

\section{LIST OF REFERENCES}

Autton, N. ed. 1971 Christianity and Change, London: SPCK.

Barmen Declaration. 1984. Journal of Theology for Southern Africa, Vol. 1(46-47).

Baum, G. 1975. Religion and alienation: A theological reading of sociology. New York: Paulist Press. 
Bettenson, H.1964. Documents of the Christian Church, London: Oxford University Press.

Bonhoeffer, D.1993. Ethics. London: SCM Press.

Bowen, R. 1996. So I send you. London: SPCK.

Brown, P. 1969. Augustine of Hippo. Berkeley: University of California.

Calvin, J. 1936. Institutes of the Christian religion. Philadelphia: Board of the Presbyterian Church.

Chadwick, H. 1988. The early church. London: Penguin Group.

Church: www.calvin.edu/academic/philosophy.pdf (accessed 26/10/2014).

Cone, J. 1986. Speaking the truth: Ecumenism, liberation and, black theology. Grand Rapids: Eerdmans.

De Gruchy, J. 1984. Bonheoffer and South Africa. Grand Rapids: Eerdmans.

Dube, J. 2006. A socio-political agenda for the twenty-first century Zimbabwe Church: Empowering the excluded. Lewiston: Edwin Mellen Press.

Dulles, A. 1987. Models of the church. New York: Doubleday.

Freire, P. 1970. Pedagogy of the oppressed. New York: Continuum.

Gundani, P. 2008. Prophecy, politics and power: Changing relations between the Catholic Church and the Zimbabwean state (1980-2007), www.paulgundani.com (accessed 23/07/2013).

Hallencreutz, C.F. and A.M. Moyo. 1988. Church and state in Zimbabwe. Gweru: Mambo Press.

Hastings, J. 1926. Dictionary of the Apostolic Church, Vol. 2. London: T \& T Clark.

Hodgson, P.C. 1988. Revisioning the church: Ecclesial freedom in the new paradigm. Philadelphia: Fortress Press.

Human Development Report 2013: United Nations Publications. 14 March 2013 www. humandevelopmentreport.un.org (accessed 18 May 2013).

Kairos .1985. Kairos document: Challenge to the church. Braamfontein: ICT.

Kambudzi, A. 2000. 'The church and the forthcoming general elections.' In Democracy and good governance in Zimbabwe, T. Chikuku and A. Hungwe ed. Gweru: Mambo Press.

Kittel, G. ed. 1968. Theological dictionary of the New Testament - Volume 111 Grand Rapids: WMB Eerdmans.

Macquarie, J. 1977. Principles of Christian theology. New York: Charles Scriber's Sons.

Maxwell, D. 2006. African gifts of the spirit. Harare: Weaver Press.

McNeill, T.J. 1965. 'John Calvin on civil government.' In Calvinism and the political order, G.L. Hunt ed. Philadelphia: Westminster.

Medellin Conference. 1968. In 1973 Second General Conference of Latin America. Bishops, Washington D C: Catholic Publications.

Missiology: www.wikipedia.org/wiki/Mission (accessed 14/08/2013)

Mpofu, S. 2013, Church activism: A mission and a calling to be attained, www.zimbabweinstitute. com (accessed 13/08/2013).

Newspaper: The Zimbabwean; 15-21 June 2006: 22.

Richardson, A. ed. 1983. A dictionary of Christian theology. London: SCM Press.

St Augustine, Civitas Dei, XIX, 24. 
Mpofu The theological dilemma vis-à-vis the moral options for relevant and practical ministry ...

Villa-Vicencio, C. 1986. Between Christ and Caesar. Cape Town: David Philip.

\section{Zimbabwe Council of Churches Archives}

Zimbabwe Council of Churches: www.zcc.co.zw (accessed 16/08/2013)

ZCC April, 1980. Our call to peace and justice as the nation is born. Harare: Zimbabwe Council of Churches.

ZCC September, 2006. The Zimbabwe we want. Harare: Zimbabwe Council of Churches.

ZCC March, 2007. The unfolding events in Zimbabwe. Harare: Zimbabwe Council of Churches.

ZCC March, 2008. The forthcoming 2008 harmonised elections. Harare: Zimbabwe Council of Churches.

ZCC January, 2013. Work for peace in Zimbabwe: Pray for it! Speak it! Spread it! Do it! (Isaiah 60:1-22). Harare: Zimbabwe Council of Churches.

ZCC, ZCBC, EFZ. September, 2006. The Zimbabwe we want. Harare: Zimbabwe Council of Churches. 